\title{
Remobilization of silicic intrusion by mafic magmas during the 2010 Eyjafjallajökull eruption
}

\author{
O. Sigmarsson ${ }^{1,2}$, I. Vlastelic ${ }^{1}$, R. Andreasen ${ }^{3}$, I. Bindeman ${ }^{4}$, J.-L. Devidal ${ }^{1}$, S. Moune ${ }^{1}$, J. K. Keiding ${ }^{5}$, G. Larsen ${ }^{2}$, \\ A. Höskuldsson ${ }^{2}$, and Th. Thordarson ${ }^{6}$ \\ ${ }^{1}$ Laboratoire Magmas et Volcans, CNRS-Université Blaise Pascal-IRD, 63038 Clermont-Ferrand, France \\ ${ }^{2}$ Institute of Earth Sciences, University of Iceland, 101 Reykjavik, Iceland \\ ${ }^{3}$ Department of Earth Science and Engineering, Imperial College London, South Kensington Campus, London SW7 2AZ, UK \\ ${ }^{4}$ Department of Geological Sciences, 1272 University of Oregon, Eugene, OR, USA \\ ${ }^{5}$ GeoForschungsZentrum Potsdam, Telegrafenberg, 14473 Potsdam, Germany \\ ${ }^{6}$ School of GeoScience, University of Edinburgh, Grant Institute, Edinburgh EH9 3JW, UK
}

Received: 14 June 2011 - Published in Solid Earth Discuss.: 8 July 2011

Revised: 19 October 2011 - Accepted: 29 October 2011 - Published: 2 December 2011

\begin{abstract}
Injection of basaltic magmas into silicic crustal holding chambers and subsequent magma mingling or mixing is a process that has been recognised since the late seventies as resulting in explosive eruptions. Detailed reconstruction and assessment of the mixing process caused by such intrusion is now possible because of the exceptional time-sequence sample suite available from the tephra fallout of the 2010 summit eruption at Eyjafjallajökull volcano in South Iceland. Fallout from 14 to 19 April contains three glass types of basaltic, intermediate, and silicic compositions recording rapid magma mingling without homogenisation, involving evolved FeTi-basalt and silicic melt with composition identical to that produced by the 1821-1823 AD Eyjafjallajökull summit eruption. The time-dependent change in the magma composition suggests a binary mixing process with changing end-member compositions and proportions. Beginning of May, a new injection of primitive basalt was recorded by deep seismicity, appearance of Mgrich olivine phenocrysts together with high sulphur dioxide output and presence of sulphide crystals. Thus, the composition of the basaltic injection became more magnesian and hotter with time provoking changes in the silicic mixing end-member from pre-existing melt to the solid carapace of the magma chamber. Finally, decreasing proportions of the mafic end-member with time in the erupted mixedmagma demonstrate that injections of Mg-rich basalt was the motor of the 2010 Eyjafjallajökull explosive eruption, and
\end{abstract}

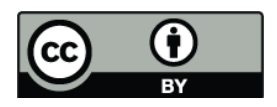

Correspondence to: O. Sigmarsson (olgeir@ raunvis.hi.is) that its decreasing inflow terminated the eruption. Significant quantity of silicic magma is thus still present in the interior of the volcano. Our results show that detailed sampling during the entire eruption was essential for deciphering the complex magmatic processes at play, i.e. the dynamics of the magma mingling and mixing. Finally, the rapid compositional changes in the eruptive products suggest that magma mingling occurs on a timescale of a few hours to days whereas the interval between the first detected magma injection and eruption was several months.

\section{Introduction}

Improved understanding of volcanic plumbing-systems is needed for better interpretations of precursors to volcanic eruptions. While deformation and seismic studies yield real-time information of physical changes beneath a volcano, geochemical investigation of the eruptive products allows identification of magma sources and quantification of magmatic processes leading to an eruption. Here, we use petrological and geochemical evidences, obtained on a precisely dated sample-suite of lava and tephra from the 2010 Eyjafjallajökull eruption in south Iceland (Fig. 1), to evaluate the triggering mechanism for the 2010 summit eruption and to quantify the magma differentiation processes. We show that basaltic injection remobilized older silicic magma, causing explosive eruption of inhomogeneous mixture of mingled magma. Such mechanical magma mixing triggering an eruption has been frequently inferred from mingled magma deposits (e.g. Sparks et al., 1977; Eichelberger, 1980;

Published by Copernicus Publications on behalf of the European Geosciences Union. 


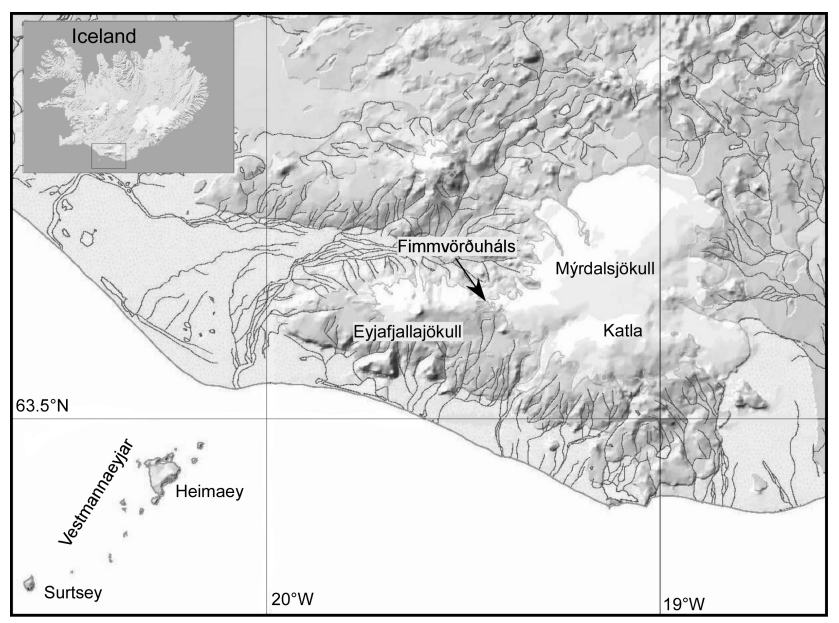

Fig. 1. Shaded relief map showing Eyjafjallajökull and Mýrdalsjökull ice-caps and the volcanic systems Vestmannaeyjar, Eyjafjallajökull and Katla. The pass between the two ice-caps, Fimmvörðuháls, was the location of the basaltic flank eruption preceding the summit eruption of Eyjafjallajökull in 2010.

Nakamura, 1995; Clynne, 1999; Suzuki and Nakada, 2007; Pallister et al., 2008; Tonarini et al., 2009). Furthermore, we demonstrate how fast the composition and proportions of the mixing end-members changed, which is relevant for understanding the dynamics of magma mixing in general.

\section{The Eyjafjallajökull 2010 eruption}

Over the last fifteen years, episodic seismic swarms and inflation-induced deformation have been taken to indicate sill injections at mid-crustal depth beneath Eyjafjallajökull volcano (Guðmundsson et al., 2010; Sigmundsson et al., 2010; Hjaltadóttir et al., 2011). A deep-sourced inflation started late December 2009, accompanied by increase in seismicity. Deformation and earthquake activity continued until late 20 March 2010, when a flank eruption broke out on a radial fissure at the Fimmvörðuháls Pass between Eyjafjallajökull and Mýrdalsjökull ice-caps (Fig. 1). The eruption produced a lava field and two scoria cones comprised of olivine- and plagioclase-phyric and relatively primitive mildly-alkaline basalt until 12 April (Fig. 2). This was followed by a seismic swarm that migrated rapidly from a depth of more than $7 \mathrm{~km}$ towards the summit of the volcano (Hjaltadóttir et al., 2011), culminating in an explosive eruption in the early morning on 14 April. Magma-water interaction was intensive during the first two days but gradually declined, and the activity became purely magmatic by 21 April. During the first five days, magma discharge was on the order of $10^{6} \mathrm{~kg} \mathrm{~s}^{-1}$, dropped to $10^{4}-10^{5} \mathrm{~kg} \mathrm{~s}^{-1}$ until early May when activity picked up and reached a discharge of $10^{6} \mathrm{~kg} \mathrm{~s}^{-1}$ again on 5-6 May, followed by an irregular decline in discharge until the end of the eruption in late May. The magma produced is of a ben- moreitic to trachytic composition (Fig. 3a) with very fine to fine ash that disturbed air-traffic over Europe for extended periods in April and May.

\section{Samples}

Our sample suite is comprised of basaltic lava (FH-1) and tephra (FH-2) from the initial phase of the flank eruption at Fimmvörðuháls, a tephra (FH-3) collected directly from the fallout from the plume on 1 April, and lava (FH-4) from the last stage of the fissure eruption. The benmoreitic sample suite includes tephra collected 15 April (EJ-1), a composite sample of tephra produced 17-19 April (EJ-2), and tephra from 22 April (EJ-3), 27 April (EJ-4), and 5 May tephra (EJ5 ), in addition to two bread-crust bombs of trachyte composition (EJ-6,7) from the final days of the eruption, collected on 3 June 2010 from the surface of $45 \mathrm{~m}$ thick tephra pile on the eastern rim of the new crater. Tephra from the 1821-1823 penultimate eruption of Eyjafjallajökull was sampled from a soil section on the western flank of the volcano for comparison. The freshly collected samples were reduced to a powder in an agate ring-mill in preparation for whole-rock analysis. Tephra samples were mounted in epoxy, whereas the 1821 tephra was washed and sieved several times until all soil remains were eliminated. Two size fractions were mounted in epoxy and polished before in-situ analysis. No alteration of the glass fragments was observed. The exact timing of our samples is fundamental for precisely deciphering the magma dynamics prior to and during the eruption.

\section{Methods}

\subsection{Microanalytical Techniques}

\subsubsection{Electron probe microanalyses}

Major element compositions of crystals and glasses were determined on a Cameca SX100 electron microprobe at the Laboratoire Magmas et Volcans of Clermont-Ferrand. Operating conditions were $15 \mathrm{kV}$ accelerating voltage and $15 \mathrm{nA}$ focused beam for minerals. Synthetic and natural minerals standards were used for calibration, with counting time set at $10 \mathrm{~s}$ for all elements. During glass analyses, analytical conditions were adjusted to minimise sodium mobility; basaltic and andesitic/dacitic tephra were analysed at $4 \mathrm{nA}$ and $2 \mathrm{nA}$ beam current, respectively, with a $10 \mu \mathrm{m}$ defocused beam. Optimized mixture of minerals standards (synthetic and natural) and glasses (A-THO and VG2) was used for calibration. The counting time was $10 \mathrm{~s}$ for $\mathrm{Na}, \mathrm{Si}, \mathrm{Ca}, \mathrm{Ti}$ and $\mathrm{P} ; 20 \mathrm{~s}$ for $\mathrm{Al}$ and $\mathrm{Mg} ; 30 \mathrm{~s}$ for $\mathrm{Mn}$, and $40 \mathrm{~s}$ for $\mathrm{K}$ and $\mathrm{Fe}$. Secondary international glass standard USGS VG A-99 (Jarosewich et al., 1979; Thornber et al., 2002) was analysed during each session to monitor for possible instrumental drift. Analyses during three days in a row, yield relative standard deviation 

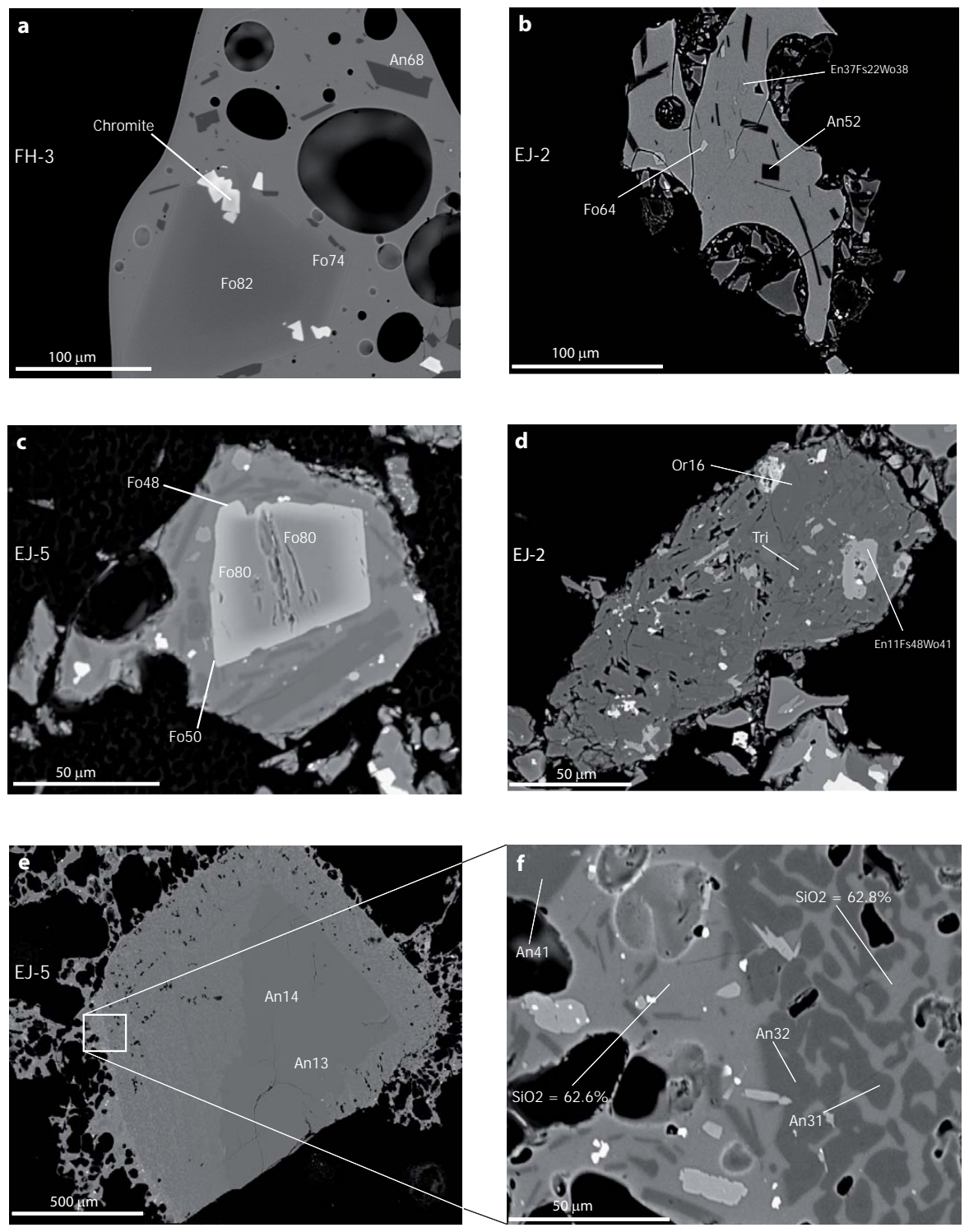

Fig. 2. Backscattered-electron images of individual tephra grains from the 2010 Eyjafjallajökull eruption: (a) basalt produced 1 April during the flank eruption at Fimmvörðuháls; (b) evolved basalt emitted together with tephra of silicic and intermediate composition during the early (17-19 April) explosive phase (note the bent plagioclase lath that grew contemporaneously with the large vesicle illustrating gas exsolution driven crystallisation); (c) cracked Mg-rich olivine-core mantled with iron-richer olivine set in partly crystalline groundmass from 5 May suggests injection of primitive basalt into the silicic magma body; (d) microsyenitic fragment composed of alkali feldspar, sodic plagioclase, ferrohedenbergite, tridymite and fluorite minerals; (e-f) destabilised oligoclase that upon melting yielded trachytic melt and calcium-richer plagioclase (see text for further discussion). Sample numbers are given at the left boundary of each image.

of $0.6 \%$ for $\mathrm{SiO}_{2}, 1-2 \%$ for $\mathrm{TiO}_{2}, \mathrm{Al}_{2} \mathrm{O}_{3}$ and $\mathrm{CaO}, 2.2 \%$ for $\mathrm{FeO}$, and $3.3 \%$ for $\mathrm{Na}_{2} \mathrm{O}$ and $\mathrm{K}_{2} \mathrm{O}$, using a single set of calibration values.

\subsubsection{Laser ablation inductively coupled plasma mass spectrometry}

Trace element analyses in glasses were performed at the Laboratoire Magmas et Volcans (Clermont-Ferrand) using a Resonetics M50 EXCIMER laser (193 nm) coupled to an Ag- ilent $7500 \mathrm{cs}$ ICP-MS. The laser was operated at $6 \mathrm{~mJ}$ energy, $2 \mathrm{~Hz}$ repetition rate and a $11 \mu \mathrm{m}$ spot size diameter. Ablation gas was pure helium; nitrogen $\left(7 \mathrm{ml} \mathrm{min}{ }^{-1}\right)$ and argon were mixed with the carrier gas via Y-connectors between the ablation cell and ICP-MS. Analysis duration was split up in two distinct parts: $40 \mathrm{~s}$ background acquisition followed by $50 \mathrm{~s}$ data acquisition from the sample. Stability of signal intensity during ablation proved a good indicator of the analytical spot homogeneity. 
The raw analyses were reduced with the Glitter software (van Achterberg et al., 2001), using $\mathrm{CaO}$ concentrations (measured earlier by electron microprobe) as internal standard. NIST 612 glass was used as the primary standard; NIST 610, BCR2-G and A-THO, periodically analyzed during the laser sessions, were used as reference materials for run quality control. The two latter reference glasses have similar composition as the analyzed sample and are therefore well suited to estimate precision and accuracy. Despite the small spot size, precision and accuracy were always better than $10 \%$ for all the elements at $95 \%$ confidence level.

\subsection{Whole-rock analysis}

\subsubsection{Major- and trace element concentrations}

About $100 \mathrm{mg}$ of powder sample were fluxed with lithium metaborate (proportions 1:3) in a carbon crucible using an induction furnace. The melt-pearl was immediately dissolved in diluted nitric acid and diluted 2000 times before ICP-AES analysis. Another $100 \mathrm{mg}$ powder aliquot was dissolved in concentrated $\mathrm{HF}-\mathrm{HNO}_{3}$, evaporated to near dryness and re-dissolved in $7 \mathrm{MHNO}_{3}$. The aliquot was evaporated to near dryness and subsequently diluted in $\mathrm{HNO}_{3} \quad 0.4 \mathrm{M}$ to reach a total dilution factor of 5000 for determination of trace element abundances by quadrupole ICP-MS (Agilent 7500, Laboratoire Magmas et Volcans). The reaction cell (He mode) was used to reduce interferences on masses ranging from 45 (Sc) to 75 (As). The signal was calibrated externally with a reference basaltic standard (BHVO-2, batch 759) dissolved as samples, and employed the GeoReM preferred values (http://georem.mpch-mainz.gwdg.de/). Both standards and pure $\mathrm{HNO}_{3} 0.4 \mathrm{M}$ were measured every 4 samples. The external reproducibility of the method, as estimated by running repeatedly different standards (BCR-2, BIR, BEN) is $<5 \%(2 \sigma)$ for most lithophile elements and $<15 \%$ for chalcophile elements.

\subsubsection{Oxygen isotopes}

Laser fluorination oxygen isotope analyses were performed at the University of Oregon stable isotope laboratory using a $35 \mathrm{~W} \mathrm{CO}_{2}$-laser. Bulk grain sample ranging in weight from 1.1 to $2 \mathrm{mg}$ were reacted with purified $\mathrm{BrF}_{5}$ reagent to liberate oxygen. The gases generated in the laser chamber were purified through a series of cryogenic traps held at liquid nitrogen temperature, with a mercury diffusion pump to eliminate traces of fluorine gas. Oxygen was converted to $\mathrm{CO}_{2}$ gas using a small platinum-graphite converter, and then the $\mathrm{CO}_{2}$ gas was analyzed on a MAT 253 mass spectrometer integrated to the laser line. Five aliquots of standards were analyzed together with the unknown samples; Gore Mt Garnet $\left(\delta^{18} \mathrm{O}=5.75 \%\right)$ was used in the standard set. Day-today $\delta^{18} \mathrm{O}$ variability on the standards ranged from -0.1 to + $0.25 \%$, and these values were added to the unknown sam- ples to correct for day-to-day variability and absolute values on SMOW scale. The obtained precision on the standards is better than $0.13 \%$ and $0.01 \%$ in two sessions at 1 standard deviation.

\subsubsection{Isotope ratios of $\mathrm{Sr}$ and $\mathrm{Nd}$}

About 100-150 mg of rock powder (chips for FH-3) were weighed into Teflon beakers for the samples and rock standards and leached for an hour in warm $6 \mathrm{M} \mathrm{HCl}$. After leaching, the samples were washed in Milli-Q water and dissolved in a 2:1 mixture of concentrated $\mathrm{HNO}_{3}$ and $\mathrm{HF}$ on a hotplate for 3 days. After drying down, the sample residues were redissolved in $6 \mathrm{M} \mathrm{HCl}$, dried down and redissolved again in $6 \mathrm{M} \mathrm{HCl}$ to obtain clear sample solutions. The samples for $\mathrm{Sr}$ and $\mathrm{Nd}$ analysis were dried down and redissolved in $1 \mathrm{M}$ HNO3 and passed through TRU.Spec column chemistry; the $\mathrm{Sr}$ and $\mathrm{Nd}$ fractions were further purified through Sr.spec and LN.spec column chemistries, respectively (Pin et al., 1994; Pin et al. 1997).

The $\mathrm{Sr}$ samples were analysed at the Imperial College London MAGIC laboratories and Laboratoire Magmas et Volcans in Clermont-Ferrand on Triton TIMS in static mode. Rubidium interferences were monitored and corrected for, but were always lower than $40 \mathrm{ppm}$. Data were corrected for instrumental mass fractionation using the exponential law and ${ }^{88} \mathrm{Sr} /{ }^{86} \mathrm{Sr}=8.375209$. Six analyses of NIST SRM $987 \mathrm{in}-$ terspersed with the samples gave an average ${ }^{87} \mathrm{Sr} /{ }^{86} \mathrm{Sr}$ value of $0.710251 \pm 8(2 \sigma)$.

Neodymium was analyzed in static mode and data were corrected for instrumental mass fractionation using the exponential law, and ${ }^{146} \mathrm{Nd} /{ }^{144} \mathrm{Nd}=0.7219$. Samples were analyzed in two analytical sessions: during the first, average value of the JNdi standard was ${ }^{143} \mathrm{Nd} /{ }^{144} \mathrm{Nd}=0.512099 \pm 20$; during the second, ${ }^{143} \mathrm{Nd} /{ }^{144} \mathrm{Nd}=0.512059 \pm 20$. Sample data were normalized to ${ }^{143} \mathrm{Nd} /{ }^{144} \mathrm{Nd}$ value of JNdi of 0.512113 . Samarium interferences were monitored and corrected for during the run; they were always lower than $100 \mathrm{ppm}$.

\section{Results and discussion}

Major-element concentrations show that the basalt of the flank eruption is mildly alkaline in composition (Table 1), similar to the magma erupted during the first half of the 1963-1967 Surtsey eruption in the Vestmannaeyjar volcanic system, $65 \mathrm{~km}$ south of Eyjafjallajökull (e.g. Jakobsson, 1979; Furman et al., 1991; Sigmarsson et al., 2009). Euhedral and normally zoned phenocrysts of olivines $\left(\mathrm{Fo}_{87-71}\right)$ and plagioclases $\left(\mathrm{An}_{86-61}\right)$ are abundant in addition to rare chromian spinel (inclusions in olivines) and clinopyroxene (Mg-number $(100 \times$ molar ratio of $\mathrm{MgO}$ over $\mathrm{MgO}+\mathrm{FeO})=76-65$ ). Glomerocrysts of olivine, plagioclase and clinopyroxene display more evolved 
Table 1. Whole-rock major- and trace-element concentrations and Sr-, Nd- and O-isotope ratios in Eyjafjallajökull 2010 products.

\begin{tabular}{|c|c|c|c|c|c|c|c|c|c|c|c|c|c|c|c|c|}
\hline Sample \# & FH-1 & FH-2 & FH-3 & FH-4 & EJ-1 & EJ-3 & EJ-4 & EJ-5 & EJ-6 & EJ-7 & EJ-5, & EJ-6' & EJ-7' & BHVO-1 & BHVO-1, & $\begin{array}{c}\text { BHVO- } 1 \text { certified } \\
\text { values }\end{array}$ \\
\hline $\mathrm{SiO}_{2}$ & 46.3 & 46.29 & 46.81 & 45.93 & 56.62 & 55.28 & 55.05 & 57.81 & 61.26 & 57.57 & 57.24 & 61.44 & 57.58 & 49.3 & 49.39 & 49.94 \\
\hline $\mathrm{TiO}_{2}$ & 2.99 & 3.05 & 2.90 & 2.73 & 1.72 & 1.77 & 1.8 & 1.52 & 1.17 & 1.58 & 1.5 & 1.12 & 1.49 & 2.68 & 2.69 & 2.71 \\
\hline $\mathrm{Al}_{2} \mathrm{O}_{3}$ & 14.95 & 15.12 & 15.09 & 14.88 & 14.95 & 14.74 & 15.02 & 14.97 & 14.56 & 14.61 & 14.95 & 14.89 & 14.87 & 13.9 & 14.02 & 13.8 \\
\hline $\mathrm{Fe}_{2} \mathrm{O}_{3}-\mathrm{t}$ & 13.85 & 13.69 & 13.01 & 13.12 & 10.65 & 10.85 & 10.8 & 10.33 & 8.21 & 10.05 & 10.15 & 8.22 & 9.98 & 12.32 & 12.36 & 12.23 \\
\hline $\mathrm{MnO}$ & 0.19 & 0.18 & 0.18 & 0.18 & 0.24 & 0.23 & 0.24 & 0.24 & 0.2 & 0.23 & 0.23 & 0.19 & 0.22 & 0.17 & 0.17 & 0.17 \\
\hline $\mathrm{MgO}$ & 8.77 & 8.21 & 8.50 & 9.05 & 2.23 & 3.6 & 2.95 & 3.2 & 2.3 & 3.56 & 3.21 & 2.21 & 3.43 & 7.16 & 7.2 & 7.23 \\
\hline $\mathrm{CaO}$ & 9.9 & 10.03 & 10.28 & 9.89 & 5.37 & 5.89 & 5.95 & 5.33 & 4.02 & 5.27 & 5.38 & 4.11 & 5.23 & 11.62 & 11.5 & 11.4 \\
\hline $\mathrm{Na}_{2} \mathrm{O}$ & 2.73 & 2.74 & 2.97 & 3.14 & 5.24 & 5.31 & 5.86 & 5.33 & 5.77 & 5.19 & 5.35 & 5.61 & 5.24 & 2.29 & 2.48 & 2.26 \\
\hline $\mathrm{K}_{2} \mathrm{O}$ & 0.63 & 0.56 & 0.67 & 0.59 & 1.74 & 1.59 & 1.61 & 1.81 & 2.56 & 1.86 & 1.81 & 2.33 & 1.82 & 0.51 & 0.51 & 0.52 \\
\hline $\mathrm{P}_{2} \mathrm{O}_{5}$ & 0.4 & 0.41 & 0.42 & 0.39 & 0.48 & 0.38 & 0.39 & 0.34 & 0.21 & 0.34 & 0.33 & 0.2 & 0.31 & 0.26 & 0.26 & 0.27 \\
\hline $\mathrm{H}_{2} \mathrm{O}+$ & 0.04 & 0.08 & 0.17 & 0.15 & 0.58 & 0.18 & 0 & 0.03 & 0.01 & 0.03 & -0.03 & 0.01 & 0.03 & 0.16 & 0.16 & 0.16 \\
\hline $\mathrm{H}_{2} \mathrm{O}-$ & -0.85 & -0.89 & -0.84 & -0.78 & 0.03 & 0.19 & 0 & -0.3 & -0.27 & -0.47 & -0.3 & -0.27 & -0.47 & 0.05 & 0.05 & 0.05 \\
\hline Total & 99.96 & 99.55 & 100.16 & 99.33 & 99.92 & 100.08 & 99.74 & 100.67 & 100.07 & 99.88 & 99.9 & 100.13 & 99.82 & 100.47 & 100.86 & 100.8 \\
\hline $\mathrm{Rb}$ & 12.0 & & 12.8 & 11.9 & 38.8 & 36.1 & 35.3 & 41.1 & 54.9 & 41.9 & & & & & & \\
\hline $\mathrm{Sr}$ & 452 & & 456 & 458 & 346 & 342 & 355 & 313 & 217 & 299 & & & & & & \\
\hline Th & 1.69 & & 1.81 & 1.71 & 5.62 & 5.16 & 5.04 & 5.91 & 7.93 & 6.09 & & & & & & \\
\hline U & 0.535 & & 0.564 & 0.538 & 1.73 & 1.61 & 1.56 & 1.83 & 2.45 & 1.86 & & & & & & \\
\hline$\delta^{18} \mathrm{O} \%$ & 5.83 & & 5.43 & & 5.96 & 5.58 & & & 5.48 & & & & & & & \\
\hline sd & 0.19 & & 0.24 & & 0.18 & 0.20 & & & 0.02 & & & & & & & \\
\hline${ }^{87} \mathrm{Sr} /{ }^{86} \mathrm{Sr}$ & 0.703259 & & 0.703254 & & 0.703257 & 0.703246 & & 0.703241 & 0.703245 & & & & & & & \\
\hline 2SE & 0.000006 & & 0.000007 & & 0.000008 & 0.000007 & & 0.000008 & 0.000006 & & & & & & & \\
\hline${ }^{143} \mathrm{Nd} /{ }^{144} \mathrm{Nd}$ & 0.512998 & & 0.512985 & & 0.513004 & 0.513000 & & 0.513003 & 0.512993 & & & & & & & \\
\hline $2 \mathrm{SE}$ & 0.000005 & & 0.000003 & & 0.000006 & 0.000005 & & 0.000004 & 0.000005 & & & & & & & \\
\hline
\end{tabular}

Major- and trace-element concentrations are given in wt\%, and ppm, respectively. Abbreviations SE and sd denote standard error and standard deviation, respectively.

composition and oscillatory zonation (Fo57-68, An ${ }_{79-68}$, Cpx Mg-number: 79-63). The magma is highly vesiculated and the groundmass is largely crystallized (Fig. 2). The interstitial glass has evolved FeTi-basaltic composition similar to segregation veins at Surtsey and Holocene lavas from the Katla volcano (Sigmarsson et al., 2009; Óladóttir et al., 2008). Less evolved basaltic glass compositions are preserved in melt inclusions of olivine and plagioclase phenocrysts (Moune et al., 2011). In contrast, bulk samples of tephra from the explosive phase of the 2010 Eyjafjallajökull eruption are of a benmoreitic composition (Table 1). During the summit eruption, phenocryst compositions vary greatly, with olivines ranging from $\mathrm{Fo}_{80}$ (Fig. 2) to $\mathrm{Fo}_{46}$, feldspars varying from $\mathrm{An}_{69}$ to $\mathrm{An}_{9}$, and $\mathrm{Mg}$-number of clinopyroxene ranging from 72 down to 19. Magnetite is abundant and traces of apatite, pyrite and orthopyroxene are also present. Both the plagioclases and the clinopyroxenes display an inverse chemical zonation (e.g. Fig. 2e-f), with a core having, respectively, lower An content and Mg-number. Such compositional zonation is readly explained by magma mixing. In contrast, zoned olivines have a core with higher Fo (Fig. 2c). Noteworthy are microgranitic fragments composed of anorthoclase $\left(\mathrm{An}_{1.2} \mathrm{Or}_{32}\right)$, tridymite, ferrohedenbergite $\left(\mathrm{Mg}\right.$-number $\left.=19 ; \mathrm{En}_{11} \mathrm{Fs}_{48} \mathrm{Wo}_{41}\right)$ and fluorite emitted during the first days of the summit eruption (Fig. 2d).

The major-element concentration variations for the wholerock and glass samples are shown in Fig. 3, where $\mathrm{CaO}$ vs. $\mathrm{MgO}$ are plotted (a) and the molar ratio of $\mathrm{CaO}$ over $\mathrm{Al}_{2} \mathrm{O}_{3}$ is displayed as a function of the $\mathrm{Mg}$-number (b). The wholerock $\mathrm{CaO} / \mathrm{MgO}$ decreased from 2.41 in the initial phase (sample EJ-1) to 1.48 in bread-crust bombs from the final stage of the eruption. Whole-rock sample of the first tephra (15 April) plots on a binary mixing line defined by the inter- stitial glass of the Fimmvörðuháls basalt and the glass composition of the 1821-1823 AD rhyolitic tephra. Three glass composition is detected in the composite tephra from 1719 April (sample EJ-2): basalt with $\mathrm{SiO}_{2}$ of $49-51 \%$, benmoreite $\left(\mathrm{SiO}_{2}=60-61 \%\right)$, and trachyte $\left(\mathrm{SiO}_{2}=69-70 \%\right.$; Fig. 3 and Table 2). These compositions plot on the same binary mixing line, indicating mechanical mixing, or mingling, of the evolved basalts with older silicic melt. In-situ glass analyses of tephra produced between 22 April and 5 May (samples EJ-3,4,5) are all of intermediate composition. These tephra show increasingly lower whole-rock $\mathrm{CaO} / \mathrm{MgO}$ values with time, indicating changes in composition of mixing end-members during the eruption. Other major elements display the same behaviour, namely a single mixing line on oxide vs. oxide diagrams for the early samples and changing ratios between the different elements for the later samples.

In-situ trace element measurements (see Table 3) in the three glass types of sample EJ-2, three glass inclusions in phenocrysts of the Fimmvörðuháls flank basalt, and in tephra glass from the 1821-1823 eruption confirm the role of mingling in forming the 2010 Eyjafjallajökull benmoreite magma. Strong linear correlations are not only observed between incompatible element concentrations such as $\mathrm{Rb}$ and Th (Fig. 4), but also between those of compatible and incompatible elements (e.g. Sr versus Th). This suggests that crystal-liquid separation had probably too little time to occur. The apparent absence of fractional crystallization despite tenfold variation in Th concentrations is best explained by rapid magma mingling with minimal melt homogenisation prior to eruption. The whole-rock tephra trace element compositions (Table 1) plot on the same mixing line, illustrating that despite changing composition of the mixing endmembers during the eruption, they must have had similar 
Table 2. Electron probe microanalysis of glasses in Eyjafjallajökull's tephra.

\begin{tabular}{|c|c|c|c|c|c|c|c|c|c|c|c|c|}
\hline $\begin{array}{l}\text { Analyse } \\
\text { number }\end{array}$ & $\mathrm{SiO}_{2}$ & $\mathrm{TiO}_{2}$ & $\mathrm{Al}_{2} \mathrm{O}_{3}$ & $\mathrm{FeO}$ & $\mathrm{MnO}$ & $\mathrm{MgO}$ & $\mathrm{CaO}$ & $\mathrm{Na}_{2} \mathrm{O}$ & $\mathrm{K}_{2} \mathrm{O}$ & $\mathrm{P}_{2} \mathrm{O}_{5}$ & Total & Remarks \\
\hline EJ-1-1 & 59.64 & 1.38 & 14.93 & 8.36 & 0.29 & 1.38 & 4.00 & 5.44 & 2.33 & 0.49 & 98.26 & \\
\hline EJ-1-2 & 65.87 & 0.51 & 16.55 & 3.52 & 0.10 & 0.26 & 2.55 & 6.21 & 2.37 & 0.60 & 98.54 & \\
\hline EJ-2-1 & 50.41 & 3.88 & 12.65 & 13.70 & 0.25 & 3.78 & 8.01 & 3.47 & 1.33 & 0.81 & 98.27 & \\
\hline EJ-2-2 & 50.22 & 3.71 & 12.77 & 13.58 & 0.26 & 4.11 & 8.49 & 3.40 & 1.17 & 0.82 & 98.52 & \\
\hline EJ-2-3 & 51.23 & 3.95 & 12.59 & 14.29 & 0.24 & 3.52 & 7.71 & 3.08 & 1.53 & 1.09 & 99.23 & \\
\hline EJ-2-4 & 51.48 & 3.85 & 12.54 & 14.33 & 0.21 & 3.57 & 7.66 & 3.26 & 1.55 & 1.00 & 99.43 & \\
\hline EJ-2-5 & 51.35 & 3.90 & 12.56 & 14.31 & 0.23 & 3.54 & 7.68 & 3.17 & 1.54 & 1.05 & 99.33 & \\
\hline EJ-2-7 & 68.35 & 0.34 & 13.94 & 4.29 & 0.09 & 0.12 & 1.06 & 5.30 & 3.69 & 0.04 & 97.24 & \\
\hline EJ-2-8 & 70.11 & 0.33 & 13.36 & 3.31 & 0.22 & 0.02 & 0.27 & 5.59 & 4.61 & 0.00 & 97.83 & \\
\hline EJ-2-9 & 59.07 & 1.59 & 14.85 & 8.75 & 0.24 & 1.47 & 4.00 & 5.14 & 2.40 & 0.54 & 98.03 & Benmoreite \\
\hline EJ-2-11 & 60.09 & 1.47 & 14.74 & 8.51 & 0.33 & 1.49 & 3.89 & 5.08 & 2.51 & 0.40 & 98.51 & \\
\hline EJ-3-1 & 57.80 & 2.08 & 14.80 & 9.38 & 0.23 & 2.04 & 4.93 & 4.90 & 2.18 & 0.48 & 98.82 & to \\
\hline EJ-3-2L & 57.63 & 2.02 & 14.77 & 9.78 & 0.21 & 2.00 & 4.88 & 4.23 & 2.24 & 0.46 & 98.23 & \\
\hline EJ-3-2D & 60.49 & 1.75 & 14.24 & 9.15 & 0.29 & 1.52 & 3.89 & 3.93 & 2.63 & 0.64 & 98.54 & trachyte \\
\hline EJ-4 & 58.26 & 2.09 & 14.00 & 9.71 & 0.24 & 2.03 & 4.66 & 4.46 & 2.37 & 0.49 & 98.30 & \\
\hline EJ-5-1.1 & 63.59 & 1.26 & 14.09 & 8.17 & 0.17 & 1.03 & 2.79 & 3.34 & 3.09 & 0.47 & 98.00 & \\
\hline EJ-5-2.2 & 62.28 & 1.42 & 14.17 & 8.12 & 0.34 & 1.25 & 3.08 & 3.25 & 2.93 & 0.40 & 97.23 & \\
\hline EJ-5-2.3 & 62.77 & 1.25 & 14.57 & 7.82 & 0.30 & 1.16 & 3.09 & 3.97 & 3.05 & 0.43 & 98.42 & \\
\hline EJ-5-4.1 & 60.96 & 1.69 & 14.36 & 8.20 & 0.24 & 0.58 & 2.26 & 4.75 & 2.12 & 0.40 & 95.58 & \\
\hline EJ-5-4.2 & 57.29 & 1.66 & 16.01 & 10.13 & 0.24 & 1.60 & 4.44 & 4.95 & 2.73 & 0.28 & 99.31 & \\
\hline EJ-5-4.4 & 58.83 & 1.62 & 16.40 & 10.04 & 0.13 & 0.97 & 2.46 & 5.38 & 3.81 & 0.37 & 100.02 & \\
\hline EJ-5-4.5 & 57.52 & 1.55 & 15.92 & 10.12 & 0.20 & 1.94 & 5.14 & 3.93 & 3.03 & 0.37 & 99.73 & \\
\hline EJ-5-10.1 & 61.76 & 1.49 & 14.45 & 8.20 & 0.14 & 1.37 & 3.28 & 4.30 & 2.88 & 0.44 & 98.30 & \\
\hline EJ-5-10.2 & 62.33 & 1.41 & 14.79 & 6.38 & 0.20 & 1.17 & 3.50 & 4.62 & 3.07 & 0.36 & 97.84 & \\
\hline EJ-5-11.1 & 61.77 & 1.36 & 13.80 & 7.55 & 0.30 & 1.19 & 3.15 & 4.56 & 4.02 & 0.45 & 98.16 & \\
\hline EJ-5-11.2 & 61.77 & 1.34 & 14.04 & 8.19 & 0.42 & 1.17 & 3.28 & 4.71 & 3.97 & 0.61 & 99.51 & \\
\hline EJ-5-11.3 & 61.09 & 1.36 & 14.03 & 8.14 & 0.34 & 1.19 & 3.12 & 4.70 & 4.03 & 0.43 & 98.43 & \\
\hline EJ-5-14.1 & 58.34 & 2.71 & 13.46 & 11.86 & 0.35 & 1.53 & 3.47 & 5.96 & 1.82 & 0.40 & 99.90 & \\
\hline EJ-5-14.2 & 60.93 & 1.43 & 14.02 & 8.12 & 0.27 & 1.36 & 3.33 & 4.66 & 2.92 & 0.46 & 97.51 & \\
\hline EJ-5-15.1 & 62.60 & 1.41 & 14.18 & 8.37 & 0.18 & 1.25 & 3.15 & 4.85 & 3.01 & 0.43 & 99.43 & \\
\hline EJ-5-15.2 & 64.58 & 1.00 & 15.88 & 6.19 & 0.23 & 0.77 & 2.70 & 4.21 & 2.68 & 0.39 & 98.64 & \\
\hline FH-glass & 46.83 & 4.80 & 13.15 & 14.44 & 0.22 & 4.62 & 9.60 & 3.28 & 1.00 & 0.71 & 98.65 & Average of 35 analysis \\
\hline MI Fo $>86$ & 46.41 & 3.58 & 14.79 & 11.89 & 0.16 & 5.93 & 10.06 & 3.33 & 0.71 & 0.47 & 97.33 & Average of 5 analysis \\
\hline MI Plag & 46.33 & 3.33 & 14.12 & 12.15 & 0.22 & 5.78 & 9.71 & 3.48 & 0.86 & 0.42 & 96.39 & Average of 3 analysis \\
\hline Katla & 47.21 & 4.73 & 12.87 & 14.83 & 0.24 & 4.78 & 9.54 & 3.04 & 0.78 & 0.71 & 98.73 & Average of historical tephra \\
\hline EJ-1821 & 68.70 & 0.30 & 14.20 & 4.63 & 0.18 & 0.05 & 1.15 & 6.17 & 3.74 & 0.02 & 99.14 & Average of 7 grains \\
\hline
\end{tabular}

$\mathrm{Rb}-\mathrm{Th}$ and $\mathrm{Sr}-\mathrm{Th}$ ratios. Uniform $\mathrm{O}, \mathrm{Sr}$ and $\mathrm{Nd}$ isotope ratios in the whole-rock lava and tephra samples (Table 1) support this conclusion. Delta ${ }^{18} \mathrm{O}$ of $5.96 \pm 0.18 \%$ in EJ-1 is consistent with the silicic mixing end-member being formed by fractional crystallisation of mantle derived basalt similar to those erupted laterally on Fimmvörðuháls $\left(\delta^{18} \mathrm{O}=5.4\right.$ $5.8 \pm 0.2 \% 0$ ). During this process the global partition coefficient of $\mathrm{Sr}\left(\mathrm{D}_{S r}\right)$ between fractionating mineral assemblage and residual melt must have been close to unity (Fig. 4b).

The rapid magma mingling/mixing is also reflected in the highly heterogeneous and zoned mineral compositions in the benmoreitic tephra. For instance, tephra that fell during the second peak in magma discharge (i.e. 5 and 6 May) contains $50 \mu \mathrm{m}$ zoned olivine (Fig. 2c) with $10 \mu \mathrm{m}$ thick rim having a composition of $\mathrm{Fo}_{48-50}$, but a core of $\mathrm{Fo}_{80}$ indistinguishable from olivines in the Fimmvörðuháls basalts. This suggests arrival of deep-derived primitive basalts that concurs with a deep seismic swarm (originating from a depth close to the mantle-crust boundary (Hjaltadóttir et al., 2011; Bjarnason, 2008)), as well as increased magma and sulphur output as indicated, respectively, by higher eruption column on 5 May (Arason et al., 2011) and satellite observations (Carn et al., 2010), together with the appearance of sulphide crystals in the benmoreitic tephra. The new influx of more primitive basalt magma coincides with changes in the composition of the silicic mixing end-member changing to a less evolved composition, as indicated by the mixing curves and lines on Fig. 3. The composition of the final mixing end-member is present in the EJ-5 tephra and identified as low temperature melting component of a Na-rich plagioclase (Fig. 2e-f). This suggests that the stagnant residual melt, most likely since the 1821-1823 eruption, was somewhat altered by blending with 
Table 3. Trace element concentrations analysed by laser ablation ICP-MS in melt inclusions (MI) in olivines from flank basalt and in benmoritic tephra erupted from the first explosive phase.

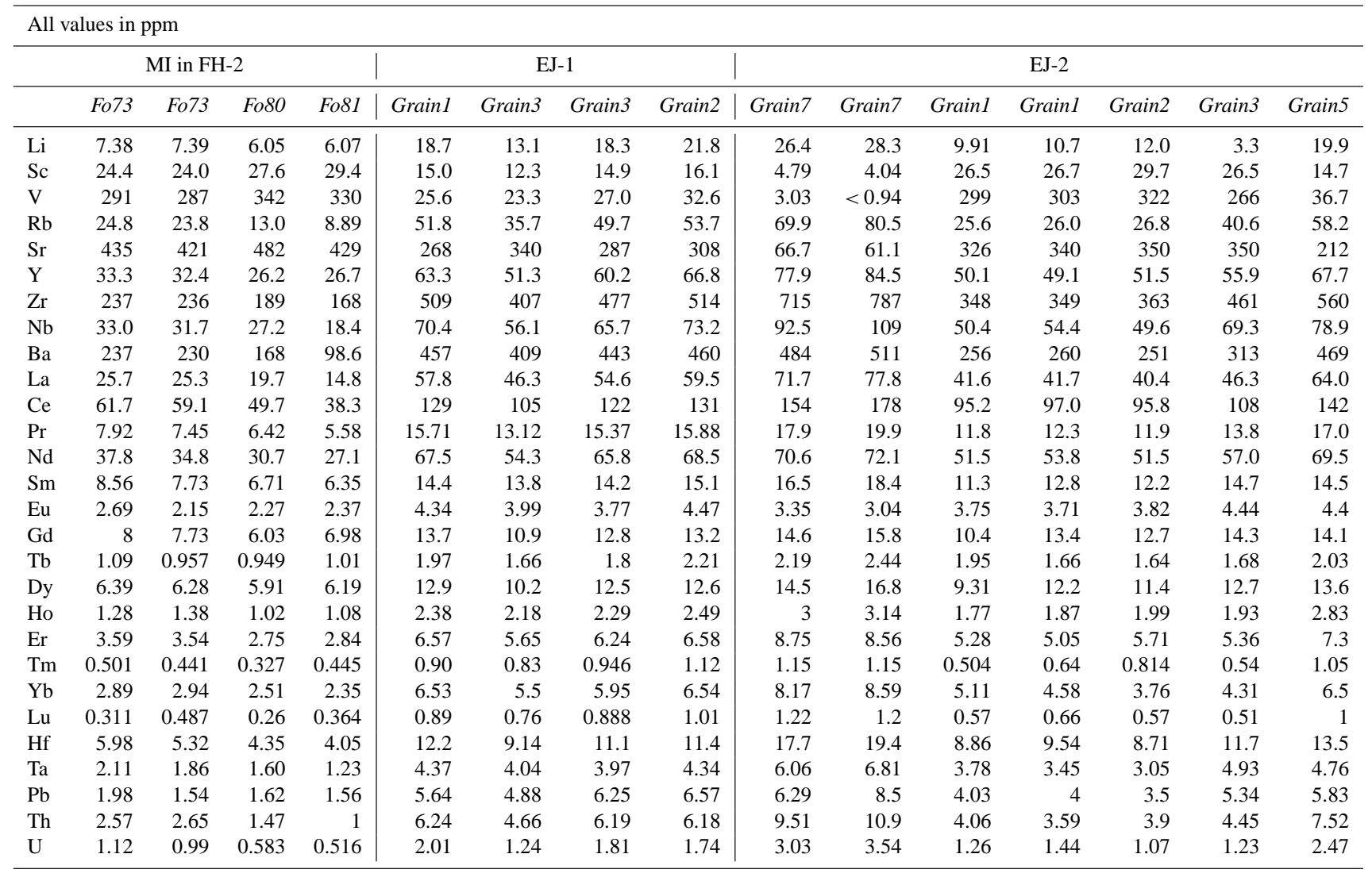

partial-melts of the magma chamber's carapace (Fig. 1d) due to interaction with newly injected and hotter mantlederived basalts. Taken together, the explosive Eyjafjallajökull eruption is best explained by mingling and mixing involving an older silicic intrusion that was heated up and remobilized by the injection of hot basalt magma that became more primitive with time. The high resolution sample suite from the 2010 Eyjafjallajökull eruption allows us to estimate a) the proportions of the basalt component in the mingled/mixed magma and its variations with time, and b) the time-dependent changes in the composition of the deepderived basalt magma (Fig. 4). These estimates are obtained from the calculated binary mixing curves shown in Fig. 3b, and from the intercept of the mixing lines with the fractional crystallisation vector of the basalts applying the lever rule (see legend to Fig. 3). The results indicate that the proportions of the basalt decreased from approximately $50 \%$ late April to less than $30 \%$ a month later, whereas the evolved FeTi-basalt composition early in the eruption was progressively replaced by more primitive basalt composition at the end.
The petrological and geochemical results obtained so far suggest the following scenario. The real-time deformation results measured during the first three months of 2010 (Sigmundsson et al., 2010) were caused by the ascent and degassing of relatively primitive and slightly alkaline basalt magma that produced, via fractional crystallisation, evolved FeTi-basalts similar to those of Katla volcano (Sigmarsson et al., 2009). This evolved basalt appears to have accumulated at depth over the three months, and only shortly before the explosive eruption (13 April) encountered the partially molten 1821-1823 residual silicic magma body beneath the summit of the volcano (Keiding and Sigmarsson, 2011). The silicic magma intrusion/chamber appears to have hindered the rise of the basalt, whereas a portion of the primitive basalt emerged further east during the Fimmvörðuháls flank eruption. Three weeks later the flank eruption stopped when the FeTi-basalt was injected into the now heated and remobilised alkaline rhyolite body directly beneath the summit crater, provoking the explosive eruption of mingled benmoreitic magma. The magnitude 2.3 earthquake that occurred 13 April (at 22:59 GMT; Hjaltadóttir et al., 2011) at $7 \mathrm{~km}$ depth may indicate the timing of the basalt injection into the 
Table 3. Continued.

\begin{tabular}{|c|c|c|c|c|c|c|c|c|c|c|c|c|c|c|c|}
\hline \multicolumn{3}{|c|}{ EJ-2 } & \multicolumn{2}{|c|}{ A-THO } & \multicolumn{11}{|c|}{ NIST610 } \\
\hline & Grain9 & Grain11 & $I$ & $I I$ & $I$ & $I I$ & III & IV & V & $V I$ & VII & VIII & $I X$ & Mean & $S D$ \\
\hline $\mathrm{Li}$ & 13.5 & 18.6 & 28.9 & 28.9 & 465 & 468 & 456 & 468 & 461 & 467 & 469 & 468 & 467 & 465 & 4.11 \\
\hline $\mathrm{Sc}$ & 10.4 & 14.7 & 7.48 & 8.79 & 449 & 448 & 441 & 455 & 452 & 455 & 449 & 450 & 451 & 450 & 4.22 \\
\hline V & 31.1 & 35.6 & 2.53 & 3.24 & 445 & 444 & 439 & 450 & 452 & 448 & 455 & 454 & 461 & 450 & 6.84 \\
\hline $\mathrm{Rb}$ & 40.6 & 53.3 & 63.3 & 63.7 & 424 & 428 & 422 & 422 & 417 & 418 & 426 & 430 & 430 & 424 & 4.74 \\
\hline $\mathrm{Sr}$ & 339 & 201 & 86.6 & 89.1 & 493 & 489 & 487 & 491 & 489 & 490 & 496 & 490 & 492 & 491 & 2.46 \\
\hline $\mathrm{Y}$ & 48.3 & 65.6 & 87.1 & 87.0 & 445 & 442 & 444 & 448 & 447 & 448 & 447 & 445 & 448 & 446 & 2.25 \\
\hline $\mathrm{Zr}$ & 387 & 517 & 443 & 455 & 418 & 416 & 413 & 415 & 410 & 413 & 409 & 408 & 405 & 412 & 4.17 \\
\hline $\mathrm{Nb}$ & 56.0 & 73.0 & 53.5 & 53.7 & 455 & 459 & 453 & 452 & 449 & 456 & 456 & 454 & 452 & 454 & 2.89 \\
\hline $\mathrm{Ba}$ & 421 & 457 & 507 & 518 & 419 & 420 & 421 & 421 & 424 & 425 & 433 & 431 & 437 & 426 & 6.43 \\
\hline $\mathrm{La}$ & 46.7 & 59.0 & 52.7 & 53.1 & 427 & 426 & 423 & 428 & 425 & 429 & 429 & 429 & 432 & 428 & 2.76 \\
\hline $\mathrm{Ce}$ & 104 & 133 & 118 & 119 & 437 & 439 & 437 & 443 & 444 & 447 & 456 & 452 & 450 & 445 & 6.74 \\
\hline $\operatorname{Pr}$ & 12.2 & 16.2 & 14.0 & 13.8 & 429 & 427 & 428 & 432 & 435 & 434 & 440 & 437 & 442 & 434 & 5.18 \\
\hline $\mathrm{Nd}$ & 48.3 & 68.4 & 57.5 & 59.9 & 433 & 434 & 427 & 416 & 409 & 413 & 415 & 411 & 411 & 419 & 9.71 \\
\hline $\mathrm{Sm}$ & 11.1 & 15.0 & 13.1 & 12.3 & 439 & 434 & 439 & 437 & 436 & 433 & 440 & 442 & 444 & 438 & 3.60 \\
\hline $\mathrm{Eu}$ & 4.03 & 4.26 & 2.47 & 2.97 & 417 & 416 & 415 & 423 & 419 & 421 & 436 & 431 & 434 & 424 & 7.95 \\
\hline $\mathrm{Gd}$ & 10.1 & 14.8 & 14.5 & 14.5 & 416 & 416 & 412 & 429 & 425 & 424 & 444 & 443 & 447 & 428 & 13.42 \\
\hline $\mathrm{Tb}$ & 1.56 & 2.13 & 2.25 & 2.18 & 405 & 404 & 400 & 414 & 407 & 413 & 423 & 421 & 420 & 412 & 8.23 \\
\hline Dy & 9.32 & 12.9 & 15.2 & 15.9 & 433 & 420 & 417 & 427 & 427 & 425 & 431 & 438 & 433 & 428 & 6.64 \\
\hline Ho & 1.82 & 2.67 & 3.1 & 3.26 & 437 & 435 & 430 & 445 & 439 & 435 & 449 & 438 & 444 & 439 & 5.97 \\
\hline $\mathrm{Er}$ & 5.02 & 7.05 & 10.3 & 10.2 & 430 & 433 & 428 & 441 & 438 & 438 & 443 & 442 & 443 & 437 & 5.59 \\
\hline $\mathrm{Tm}$ & 0.699 & 1.09 & 1.38 & 1.39 & 427 & 429 & 426 & 434 & 437 & 432 & 441 & 440 & 440 & 434 & 5.73 \\
\hline $\mathrm{Yb}$ & 4.16 & 6.86 & 9.97 & 10.1 & 456 & 456 & 444 & 459 & 455 & 459 & 464 & 467 & 462 & 458 & 6.44 \\
\hline $\mathrm{Lu}$ & 0.793 & 1.09 & 1.55 & 1.29 & 431 & 433 & 429 & 440 & 441 & 436 & 443 & 444 & 443 & 438 & 5.81 \\
\hline Hf & 8.53 & 12.1 & 12.9 & 12.1 & 389 & 393 & 388 & 396 & 402 & 400 & 406 & 406 & 405 & 398 & 7.06 \\
\hline $\mathrm{Ta}$ & 3.6 & 4.5 & 3.92 & 3.47 & 467 & 468 & 458 & 467 & 460 & 469 & 461 & 463 & 462 & 464 & 3.93 \\
\hline $\mathrm{Pb}$ & 4.77 & 5.81 & 5.99 & 5.87 & 429 & 425 & 420 & 427 & 423 & 430 & 437 & 437 & 435 & 429 & 6.02 \\
\hline Th & 4.98 & 6.59 & 6.87 & 7.24 & 437 & 440 & 437 & 442 & 445 & 443 & 447 & 450 & 448 & 443 & 4.81 \\
\hline $\mathrm{U}$ & 1.58 & 2.2 & 2.01 & 2.05 & 436 & 441 & 442 & 450 & 447 & 450 & 457 & 459 & 461 & 449 & 8.57 \\
\hline
\end{tabular}

The first two MI in olivine with Fo73 and the two A-THO analysis are duplicate analysis of the same glass patch.

The standard glass NIST610 was run as an unknown during different runs and yields the overall reproducibilty.

silicic intrusion. During the first two weeks of the explosive summit eruption, evolved basalt was involved in the magma mingling/mixing process, and thereafter the basalt became less evolved due to inflow of deeper-derived and more primitive magma. The ascent of deeper-derived basalts most likely caused the seismicity at $18-24 \mathrm{~km}$ depth observed in early May (Hjaltadóttir et al., 2011).

Decreasing mafic end-member proportions with time in the erupted mixture strongly suggests that the basaltic injection remobilized the half-solidified residual silicic magma beneath Eyjafjallajökull and that the 2010 eruption was shut off by declining basaltic intrusion rather than emptying of a silicic magma reservoir. Therefore, the next eruption at this volcano is likely to produce silicic magma with corresponding tephra production. The strong evidences for magma mingling/mixing at the origin of recent explosive eruptions elsewhere, such as at Mt. St. Helens (USA, Pallister et al., 2008) and Mt. Unzen (Japan; Nakamura, 1995), and the timerelated increasing proportions of mafic enclaves in volcanics from the on-going eruption at Soufrière Hills (Montserrat, Lesser Antilles; Barclay et al., 2010), clearly demonstrate that not only is magma mingling and mixing important as a triggering mechanism at hazardous volcanoes but also a very dynamic process. The results of the present study clearly underline how fast magma mixing components can change.

\section{Conclusions}

The explosive summit eruption of Eyjafjallajökull in 2010 was triggered by an injection of $\mathrm{Mg}$-rich basaltic magma several months earlier. This basalt stagnated below a silicic magma body - presumably residues from the penultimate alkali rhyolite eruption in 1821-1823 - degassed, partially crystallized and evolved to a FeTi-basalt. The heat and gas liberated rose up into the half-frozen silicic magma, opening a pathway for the evolved basalt that triggered the explosive eruption on 14 April through magma mingling within the silicic reservoir. In the meantime, the Mg-rich magma by-passed the central magma chamber and produced a flank eruption until the passage through the central conduit opened up. Early May, the evolved basalt was consumed 

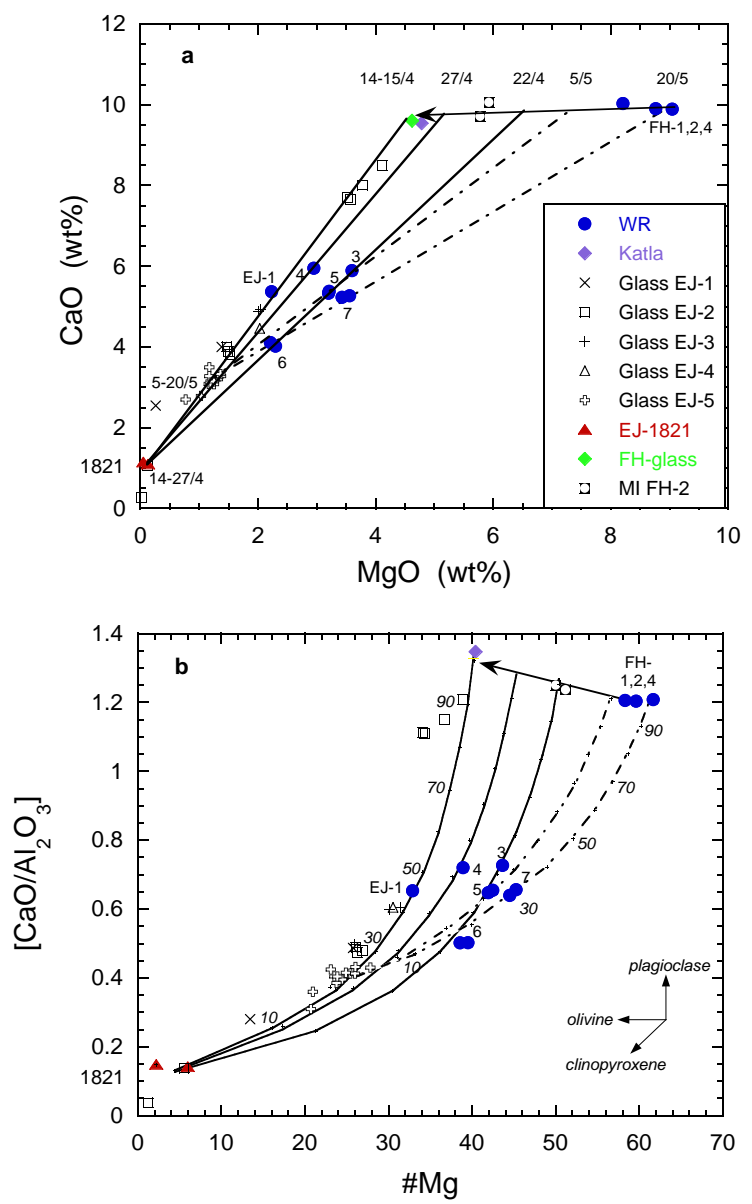

Fig. 3. Major-element variations in 2010 Eyjafjallajökull tephra and lava. (a) $\mathrm{CaO}$ versus $\mathrm{MgO}$ showing a near-horizontal fractionation vector from Fimmvörðuháls whole-rock (WR) basalt compositions (samples with prefix FH) to that of the corresponding interstitial glasses and Katla 1918 basalt glasses (Óladóttir et al., 2008). Mixing lines between these evolved basalt compositions $(\mathrm{MgO} \sim 4.5$; $\mathrm{CaO} \sim 9.5 \mathrm{wt} \%)$ and the two silicic end-members, the 1821-1823 rhyolite and oligoclase melt (open crosses; see text for further discussion) of 5 May (dash-dot line) are also shown. The intercepts of these lines with the basaltic fractionation vector are used to estimate the degree of basaltic evolution (expressed as mixing proportions between evolved and primitive basalts in Fig. 5) in the mafic mixing pole. Dates of samples corresponding to different intercepts are shown in addition to the interval of active silicic mixing poles. (b) Molar ratios of $\mathrm{CaO}$ over $\mathrm{Al}_{2} \mathrm{O}_{3}$ against the $\mathrm{Mg}$ number $(\# \mathrm{Mg}=$ molar $\mathrm{MgO}$ over the sum of $\mathrm{MgO}$ plus $\mathrm{FeO}$ calculated from total iron analysed by assuming $\mathrm{Fe}_{2} \mathrm{O}_{3} / \mathrm{FeO}$ of 0.2). In the lower right corner are shown schematically the melt composition vectors of pure mineral fractionation from basalt. These are consistent with olivine domination on the fractionation vector from FH-basalt, but the trend of EJ-2 basalt glasses indicates clinopyroxene fractionation. Binary mixing curves are calculated using the same end-member composition as in (a). Mingling and mixing proportions of basalt to silicic melt are derived from the calculated curves. Duplicate analyses of three Eyjafjallajökull bulk-tephra (EJ$5,6,7)$ indicate the overall analytical precision. Abbreviations are WR for whole-rock compositions, EJ for Eyjafjallajökull, FH for Fimmvörðuháls flank basalts and MI for melt inclusions.
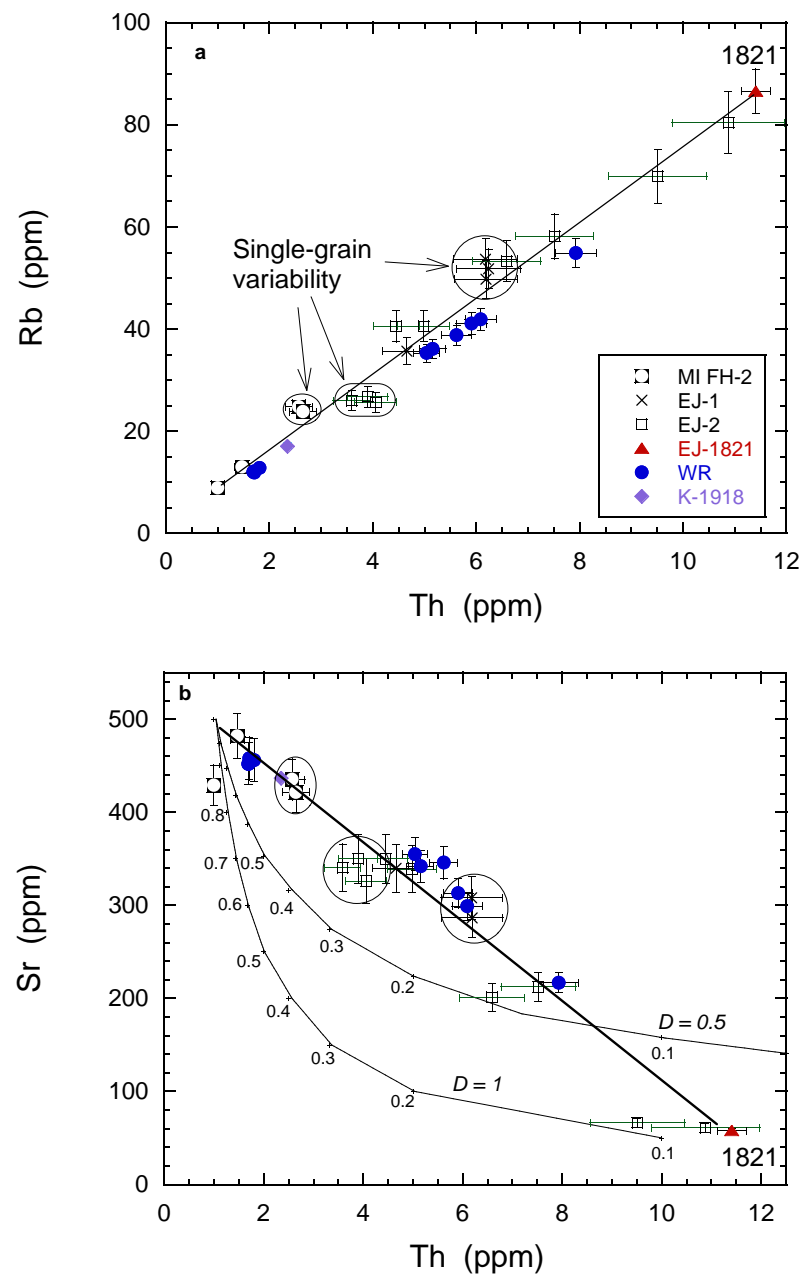

Fig. 4. Linear correlations of $\mathrm{Rb}, \mathrm{Sr}$, and Th concentrations between extreme magma compositions produced during the 2010 Eyjafjallajökull eruption. Four spot analyses of three olivine-hosted melt inclusions are shown for comparison. Larger error bars for the in-situ analysis, compared to those of whole-rock (WR), are caused by small ablation crater-size (diameter of $11 \mu \mathrm{m}$ ) due to small area of crystal-free glass patches and consequent lower count rates of each element. Multiple analyses of single grains are encircled in both panels. In (b), two curves of melt evolution during hypothetical crystal fractionation are shown for different $\mathrm{D}_{S r}$ (assuming $\mathrm{D}_{T h}$ close to 0 ) with the remaining melt fractions indicated. The origin of the 1821-1823 alkaline rhyolite will be addressed elsewhere but it is consistent with over $90 \%$ fractional crystallisation from primitive basalt. This differentiation mechanism appears dominant at Icelandic volcanoes close to the periphery of the island (Martin and Sigmarsson, 2007). Apatite fractionation, where $\mathrm{D}_{S r}$ can be as high as 5 (Prowatke and Klemme, 2006), together with that of plagioclase, having $\mathrm{D}_{S r}$ in the range 1-3 (Fabbrizio et al., 2009), account for a bulk $\mathrm{D}_{S r}$ as high as unity. See Fig. 3 for abbreviations. 


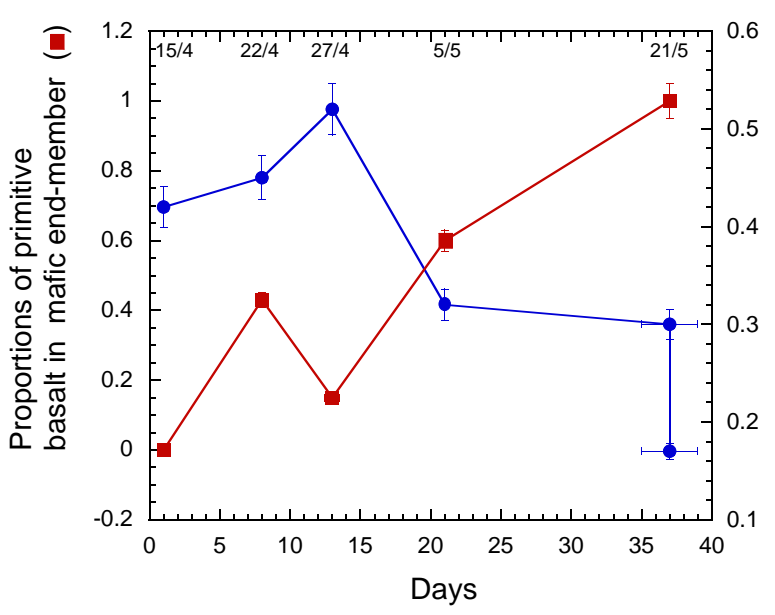

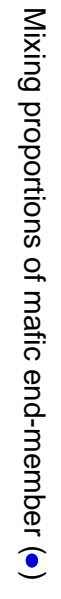

Fig. 5. Mixing (and mingling) proportions as a function of time of primitive basalt in the mafic end-member (scale on left y-axis) and that of basalt melt in the benmoritic tephra of Eyjafjallajökull. Arbitrary $5 \%$ error is assigned to the estimated magma mixing proportions that are derived from Fig. (3). The decrease of the basalt component suggests that supply of silicic magma at depth is abundant (see text for further details).

by the magma mingling/mixing and deeper Mg-rich basalt rose from a depth in excess of $20 \mathrm{~km}$ into the silicic reservoir and caused increased magma output and a corresponding higher eruption column. The additional heat brought in by the fresh intrusion caused partial melting of the microgranitic carapace, causing changes in the composition of the mixing end-members. Finally, the basalt injection declined and the eruption came to a halt.

Acknowledgements. Sigurdur R. Gislason collected sample EJ-1. Analytical assistance by C. Bosq, D. Auclair-Aubierge and M. Benbakkar was much appreciated. We are grateful to an anonymous reviewer and D. Perugini for detailed and thought provoking reviews. Direct funding from the Icelandic government and a grant from the Icelandic Research Fund (110242011 "Volcano Anatomy") is acknowledged. This article has a ClerVolc contribution number 2 .

Edited by: R. Moretti

\section{References}

Arason, P., Petersen, G.N., and Bjornsson, H.: Observations of the altitude of the volcanic plume during the eruption of Eyjafjallajökull, April-May 2010, Earth Syst. Sci. Data, 3, 9-17, 2011, http://www.earth-syst-sci-data.net/3/9/2011/.

Barclay, J., Herd, R. A., Edwards, B. R., Christopher, T., Kiddle, E. J., Plail, M., and Donovan, A.: Caught in the act: implications for the increasing abundance of mafic enclaves during the recent eruptive episodes of the Soufrière Hills volcano, Montserrat,
Geophys. Res. Lett., 37, L00E09, doi:10.1029/2010GL042509, 2010.

Bjarnason, I. Th.: An Iceland hotspot saga, Jökull, 58, 3-16, 2008.

Carn, S. A., Wang, J. Yang, K., and Krotkov, N. A.: Sulfur budget of the 2010 Eyjafjallajökull eruption derived from satellite observations, AGU Fall Meeting, Abstract V53F-08, 2010.

Clynne, M. A.: A Complex Magma Mixing Origin for Rocks Erupted in 1915, Lassen Peak, California, J. Petrol., 40, 105132, 1999.

Eichelberger, J. C.: Vesiculation of mafic magma during replenishment of silicic magma reservoirs, Nature, 288, 446-450, 1980.

Fabbrizio, A., Schmidt, M. W., Günther, D., and Eikenberg, J.: Experimental determination of Ra mineral/melt partitioning for feldspars and ${ }^{226} \mathrm{Ra}$-disequilibrium crystallization ages of plagioclase and alkali-feldspar, Earth Planet. Sc. Lett., 280, 137148, 2009.

Furman, T., Frey, F. A., and Park, K.-H.: Chemical constraints on the petrogenesis of mildly alkaline lavas from Vestmannaeyjar, Iceland: the Eldfell (1973) and Surtsey (1963-1967) eruptions: Contrib. Mineral. Petr., 109, 19-37, 1991.

Guðmundsson, M. T., Pedersen, R., Vogfjörd, K., Thorbjarnardottir, B., Jakobsdottir, S., and Roberts, M.: Eruptions of Eyjafjallajökull Volcano, Iceland: Eos, 91, 190-191, 2010.

Hjaltadóttir, S., Vogfjörð, K., and Slunga, R.: Precise seismic mapping of magma pathways before and during the 2010 Eyjafjalljökull eruptions, submitted to J. Geophys. Res., 2011.

Jakobsson, S. P.: Petrology of Recent basalts from the Eastern Volcanic Zone, Iceland: Acta Naturalia Islandica, 26, 1-103, 1979.

Jarosewich, E., Nelen, J. A., and Borberg, J. A.: Electron microprobe reference samples for mineral analysis, edited by: Fudali, R. F., Smithsonian Institution Contributions to the Earth Sciences No. 22, Smithsonian Institution Press, 68-72, 1979.

Keiding, J. K. and Sigmarsson, O.: Geothermobarometry of the 2010 Eyjafjallajökull eruption, J. Geophys. Res., in press., 2011.

Martin, E. and Sigmarsson, O.: Geographical variations of silicic magma origin in Iceland: the case of Torfajökull, Ljósufjöll and Snæfellsjökull volcanoes, Contrib. Mineral. Petr., 153, 593-605, 2007.

Moune, S., Sigmarsson, O., Schiano, P., and Thordarson, Th.: Melt inclusion in olivines from the 2010 flank eruption at Eyjafjallajökull: magma source and degassing, J. Geophys. Res., in review, 2011.

Nakamura, M.: Continuous mixing of crystal mush and replenished magma in the ongoing Unzen eruption, Geology, 23, 807-810, 1995.

Óladóttir, B., Sigmarsson, O., Larsen, G., and Thordarson, T.: Temporal evolution of the magma plumbing system beneath Katla volcano Iceland, B. Volcanol., 70, 475-493, 2008.

Pallister, J. S., Thornber, C. R., Cashman, K. V., Clynne, M. A., Lowers, H. A., Mandeville, C. W., Brownfield, I. K., and Meeker, G. P.: Petrology of the 2004-2006 Mount St. Helens lava dome - Implications for magmatic plumbing and eruption triggering, edited by: Sherrod, D. R., Sherrod, D. R., Scott, W. E., and Stauffer, P. H., A volcano rekindled; the renewed eruption of Mount St. Helens, 2004-2006, U.S. Geological Survey Professional Paper 1750, 647-702, 2008.

Pin, C., Briot, D., Bassin, C., and Poitrasson, F.: Concomitant separation of strontium and samarium-neodymium for isotopic analysis in silicate samples, based on specific extraction chromatog- 
raphy, Anal. Chim. Acta, 298, 209-217, 1994.

Pin, C. and Zaldegui, J. F. S.: Sequential separation of light rareearth elements, thorium, and uranium by miniaturized extraction chromatography: Application to isotopic analyses of silicate rocks, Anal. Chim. Acta, 339, 79-87, 1997.

Prowatke, S. and Klemme, S.: Trace element partitioning between apatite and silicate melts, Geochim. Cosmochim. Ac., 70, 45134527, 2006.

Sigmarsson, O., Thordarson, Th., and Jakobsson, S. P.: Segregations in Surtsey lavas (Iceland) reveal extreme magma differentiation during late stage flow emplacement, edited by: Thordarsson, Th., Self, S., Larsen, G., Rowland, S. K., and Hoskuldsson, A.: Studies in Volcanology: The Legacy of George Walker. Special Publications of IAVCEI: London, United Kingdom, Geol. Soc., 2, 85-104, 2009.

Sigmundsson, F., Hreinsdóttir, S., Hooper, A., Árnadóttir, T., Pedersen, R., Roberts, M. J., Óskarsson, N., Auriac, A., Decriem, J., Einarsson, P., Geirsson, H., Hensch, M., Ófeigsson, B. G., Sturkell, E., Sveinbjörnsson, H., and Feigl, K. L.: Intrusion triggering of the 2010 Eyjafjallajökull eruption, Nature, 468, 426430, 2010.
Sparks, S. R. J., Sigurdsson, H., and Wilson, L.: Magma mixing: a mechanism for triggering acid explosive eruptions, Nature, 267, 315-318, 1977.

Suzuki, Y. and Nakada, S.: Remobilization of Highly Crystalline Felsic Magma by Injection of Mafic Magma: Constraints from the Middle Sixth Century Eruption at Haruna Volcano, Honshu, Japan, J. Petrol., 48, 1543-1567, 2007.

Thornber, C. R., Sherrod, D. R., Siems, D. R., Heliker, C. C., Meeker, G. P., Oscarsson, R. L., and Kauahikaua, J. P.: Whole rock and glass major-element geochemistry of Kilauea Volcano, Hawaii, near-vent eruptive products: September 1994 through September 2001, in: US Geological Survey open file report, 0217, 2002.

Tonarini, S., D’Antonio, M., Di Vito, M., Orsi, G., and Carandente, A.: Geochemical and $\mathrm{B}-\mathrm{Sr}-\mathrm{Nd}$ isotopic evidence for mingling and mixing processes in the magmatic system that fed the Astroni volcano (4.1-3.8 ka) within the Campi Flegrei caldera (southern Italy), Lithos, 107, 135-151, 2009.

van Achterbergh, E., Ryan, C. G., Jackson, S. E., and Griffin, W. X.: Data reduction software for La-ICP-MS, edited by: Sylvester, P., Laser ablation ICP-MS in Earth Science Principles and Applications, Mineralogical Association of Canada, 239-243, 1997. 